\title{
LOLAS STEPKE, FERNANDO y DRUMOND, JOSÉ GERALDO DE FREITAS, editores
}

Bioética

\section{Santiago de Chile, Editorial Mediterráneo, 2012, 319 pp}

Este volumen es una compilación de trabajos —algunos de tipo ensayo y otros más científicos- de diecisiete autores latinoamericanos invitados a escribir desde sus propia perspectiva, convicciones e instituciones, lo que le da un sabor de amplitud continental y que los editores han facilitado al generar este diálogo bioético.

El texto lo podemos definir más bien como un manual introductorio al tema de la bioética que, como afirman los editores en el Prólogo, "aún no está zanjada la cuestión de si (...) debiera ser disciplina o profesión, o simplemente un saber-hacer instrumental al ejercicio de diversas artes, oficios y profesiones".

Si bien el libro no está "ordenado" por temas — contiene 25 capítulos o, mejor dicho, artículos-presenta un determinado orden que facilita la búsqueda de las cuestiones que son de interés más general. Así, por ejemplo, comienza con los "aspectos históricos de la ética". Allí encontramos, tal vez entre los más relevantes, "Bioética: generalidades y conceptos básicos", por su claridad; "Dimensión bioética de las profesiones", por su novedad; "Investigación científica: una perspectiva ética", muy clarificador, y "La voluntad anticipada", tratada brevemente pero con seriedad y argumentos.

También el texto pasa revista a temas como los comités de ética institucional, salud mental, medio ambiente, investigación en seres humanos y animales, aborto, vejez, trasplante de órganos, etc. En definitiva, el libro es un texto-manual que aporta en temas generales de la bioética, con la particular visión de autores latinoamericanos.

Claudio Lavados Montes 